\title{
Hydrolysis of Oil Palm Empty Fruit Bunch Fibers to Produce Sugar Hydrolyzate as Raw Material for Bioethanol Production
}

\author{
Fitriani Kasim, Anwar Kasim \\ Faculty of Agricultural Technology, University of Andalas Campus Limau Manis Padang 25163 \\ West Sumatra, Indonesia \\ E-mai : fitribcd@yahoo.com
}

\begin{abstract}
A study conducted to see the effect of the regulation and control of temperature on the length of the hydrolysis of oil palm empty fruit bunches fiber and the resulting hydrolyzate sugar levels, which will be planned to be used as raw material for bioethanol. Therefore do oil palm empty fruit bunches fiber hydrolysis with sulfuric acid (H2SO4) at low concentrations (1\%) using an autoclave with a temperature of $120^{\circ} \mathrm{C}$ and $130{ }^{\circ} \mathrm{C}$, and the time for 30, 60, 90, 120 minutes. After that the observed reducing sugar levels by using a method Luff Schoorl. The results showed that setting temperature and time influence on sugar levels resulting hydrolyzate where the optimum temperature and time to produce the highest sugar content reducing at $130{ }^{\circ} \mathrm{C}$ with a long 60 minutes, with the resulting reducing in sugar content was $3.51 \%$. The results obtained are much higher than previous studies conducted by researchers who carried out the straw fibers under the same conditions by using a solution of $1 \% \mathrm{H} 2 \mathrm{SO} 4$ and hydrolysis time 1 hour, but no temperature control and heating is only done on a gas stove, which acquired sugar $0.22 \%$. As for the gain of $0.78 \%$ sugar, hydrolysis takes 4 hours, with a concentration of $10 \%$ sulfuric acid.
\end{abstract}

Keywords - Acid Hydrolysis; Empty Fruit Bunches Palm Fiber; Reducing Sugar Levels.

\section{INTRODUCTION}

Along with the increasing public demand for petroleumbased fossil fuels, while the limited availability and the price continues to soar because of this energy is not renewable and long time span required for the supply of fuel is by nature, it is necessary to arrange other fuels are easily available and is renewable.

So far, various research continues to be done and developed until it finally found biofuels. In contrast to fossil fuels derived from fossils formed from microscopic plants and animals for hundreds of millions of years, biofuels more based on plantations and farms industry. Currently there are two commercial products for biofuels are bioethanol and biodiesel (National Team for Biofuel Development, 2008).

Bioethanol is an alcohol made from the fermentation of biomass. Fermentation can be done on starchy materials, such as cassava, corn, grain sorghum, wheat, corn and potatoes; sugary ingredients such as molasses (molasses), sugar cane, coconut sap, sweet sorghum stalk, palm sugar (palm), palm sap, gewang sap, and lignocellulosic materials such as agricultural waste form of rice straw, bagasse, corncob, cassava (tapioca waste), stems of banana or sawdust (grajen), logging waste and others (Prihandana and Hendroko, 2008; Prihandana et al., 2007).

During this time the production of bioethanol is directed to the starchy and sugary materials such as sugar cane, cassava and maize. Though these materials is basically a food source of considerable potential, so that the development of bioethanol from these foodstuffs future will be a new problem due to competition with food needs of society. Therefore, it is necessary to develop bioethanol from material that is not a food source community is primarily lignocellulosic materials thus allowing for the future utilization of industrial wastes and even the forest wood waste and the development of plantation forests as a source of energy in Indonesia (Daud, 2010).

Lignocellulosic materials which is industrial waste that has huge potential to be used as raw material for production of bioethanol is palm empty fruit bunches. Empty fruit bunches of palm is one of industrial solid waste processing palm availability is abundant throughout the year.

Lignocellulosic materials utilization as a producer of bioethanol is still constrained in processing more complex, which requires the preliminary process result of the presence of lignin, extractive substances, cellulose crystallinity and the presence of inhibitors as a byproduct during hydrolysis and fermentation process. Although the price of 
lignocellulosic materials basically cheaper and more easily available, but the cost of production is still relatively higher than sugary and starchy materials. Hence the challenge in bioconversion technologies lignocellulosic materials into bioethanol is still low productivity due still less optimal pretreatment process, hydrolysis and fermentation of glucose to bioethanol (Daud, 2010).

Hydrolysis process is a series of important steps in the process of bioethanol production. Hydrolysis process on the lignocellulosic material that is the process of converting cellulose into glucose. Hydrolysis lignocellulosic material can be done with acids or enzymes.

Acid hydrolysis can be categorized by two general approaches, namely high concentrations of acid hydrolysis a low temperatures and low concentrations of acid hydrolysis at high temperatures. However, because the price is quite expensive strong acids, acid hydrolysis of cellulose with high concentrations rarely applied commercially. The choice between these two ways are generally based on several considerations, namely the rate of hydrolysis, the rate of degradation, products and the total cost of production process (Kosaric et al., 1983 cit Apriyanti, 2008).

Apriyanti (2008), conducted a study hydrolysis lignocellulosic material such as rice straw with sulphuric acid ( $\mathrm{H} 2 \mathrm{SO} 4)$ and obtain the best results during a hydrolysis time of 240 minutes (4 hours) and 1\% H2SO4 concentration. Where the amount of glucose produced was $0.77 \%$. In this study there was no control of the temperature and pressure, where hydrolysis is done simply by heating the material above the gas stove. So that the time required to process relatively long hydrolysis for 4 hours. Time was positively correlated with the cost, so if long hydrolysis time could be reduced by controlling the temperature and pressure will be able to reduce production costs. Besides, with a controlled temperature and pressure expected hydrolysis process is complete, so that the levels of glucose obtained from cellulose hydrolysis will be higher. Therefore in this study, researchers will try to regulate and control the temperature and pressure, as well as the optimal hydrolysis time in order to obtain the maximum glucose levels by using an autoclave is equipped with temperature and pressure regulator. If glucose levels are obtained maximum, expected levels of ethanol thus obtained through the fermentation process will also be maximized.

\section{MATERIALS AND METHODS}

This study is limited only to obtain sugar hydrolyzate. Procedure to produce sugar hydrolyzate performed in several stages include preparation of oil palm empty fruit bunch fiber, chemical fiber component analysis, hydrolysis of fiber and sugar hydrolyzate analysis.

1) Preparation of Oil Palm Empty Fruit Bunch Fiber: Oil palm empty fruit bunches chopped up to the size of $\pm 5 \mathrm{~cm}$, then felted, and dried to a moisture content of $\pm 10 \%$ by using solar dryers. Fibers then smoothed using a hammer mill to powder form and sieved with a 40 mesh sieve.

2) Analysis of Chemical Components Fiber: Before testing the chemical properties of raw materials to prior determination of water content. Measurement of water content refers to TAPPI standard T 264 om-88 in Daud
(2010). While calculating levels of lignin, cellulose and holoselulosa based on Anonymous (1985).

3) Hydrolysis Fiber: Enter the empty fruit bunches of oil palm fiber into 8 pieces $250 \mathrm{ml}$ Erlenmeyer, each as much as $20 \mathrm{~g}$, then add $200 \mathrm{ml}$ of water and $1 \% \mathrm{H} 2 \mathrm{SO} 4$ (1\% of the volume of water). Comparison of the sample with $1 \%$ H2SO4 is 1: 10 (w/v). Stir with a shaker incubator at 100 $\mathrm{rpm}$ for $5 \mathrm{~min}$. Then hydrolysis in an autoclave according to treatment (temperature $120^{\circ} \mathrm{C}, 130^{\circ} \mathrm{C}$, time 30, 60, 90 and 120 minutes). Each treatment performed with 2 replications. Then strain to obtain sugar hydrolyzate.

4) Analysis of sugar hydrolyzate: Analysis of the hydrolyzate sugars include glucose and total reducing sugar levels. Determination of reducing sugar and total sugar Luff Schoorl method, the method contained in the book Analysis Procedures for Food and Agricultural Materials Slamet Sudarmadji et al (1984).

\section{RESULTS AND DISCUSSION}

\section{A. Chemical Composition of Oil Palm Empty Fruit}

Bunch Fiber From observations made on palm empty fruit bunch fiber data obtained as follows: water content $=9.16 \%$ fiber, sugar hydrolyzate $\mathrm{pH}=1$. While the chemical composition of the fibers can be seen in Table 1 .

TABLE I

CHEMICAL COMPOSITION OF OIL PALM EMPTY FRUIT BUNCH FIBER

\begin{tabular}{|l|c|}
\hline Chemical Composition & Levels (\%) \\
\hline Cellulose & 57.19 \\
\hline Hemicellulose & 5.68 \\
\hline Lignin & 31.89 \\
\hline Holocellulose & 62.87 \\
\hline
\end{tabular}

The chemical composition of oil palm empty fruit bunch fibers obtained from the results of different studies that examined Haroen and Fansukri (1995) is also different from the results of research Sudiyani (2009) cit Andayani (2012), it is suspected to be related to the origin of raw materials, sampling method and testing procedures were used (Tables II and III).

TABLE II

CHEMICAL COMPOSITION OF OIL PALM EMPTY FRUIT BUNCH FIBER (Haroen and Fansukri, 1995)

\begin{tabular}{|l|c|}
\hline Chemical Composition & Levels (\%) \\
\hline Ash content & 6.04 \\
\hline Lignin content & 15.7 \\
\hline Levels of pollen & 5.00 \\
Alpha cellulose & 36.81 \\
Holocellulose & 72.29 \\
\hline Pentose & 27.01 \\
Solubility: & \\
Cold water & 11.46 \\
\hline Hot water & 14.79 \\
\hline
\end{tabular}


TABLE III

CHEMICAL COMPOSITION OF OIL PALM EMPTY FRUIT

BUNCH FIBER (Sudiyani, 1995 cit Andayani, 2012)

\begin{tabular}{|l|c|}
\hline Chemical Composition & (\%) Weight \\
\hline Cellulose & $41.3-46.5$ \\
Hemicellulose & $25.3-33.8$ \\
Lignin & $27.6-32.5$ \\
\hline
\end{tabular}

\section{B. Reducing Sugar Levels}

From 8 treatments with 2 replications were performed by combining the temperature and time of hydrolysis of oil palm empty fruit bunch fibers reducing sugar obtained as in Table 4. Graphs can be seen in Figure 1 and 2.

TABLE IV

REDUCING SUGAR LEVELS OIL PALM EMPTY FRUIT BUNCH FIBERS WERE ACID HYDROLYZED WITH SOME COMBINATION OF TEMPERATURE AND HYDROLYSIS TIME

\begin{tabular}{|c|c|c|}
\hline \multirow{2}{*}{$\begin{array}{c}\text { Hydrolysis Time } \\
\text { (Minutes) }\end{array}$} & \multicolumn{2}{|c|}{ Reducing S ugar Levels (\%) } \\
\hline & Temperature $120^{\circ} \mathrm{C}$ & Temperature $130^{\circ} \mathrm{C}$ \\
\hline 30 & 2.06 & 3.19 \\
\hline 60 & 2.5 & 3.51 \\
\hline 90 & 2.59 & 3.25 \\
\hline 120 & 2.64 & 3.39 \\
\hline
\end{tabular}

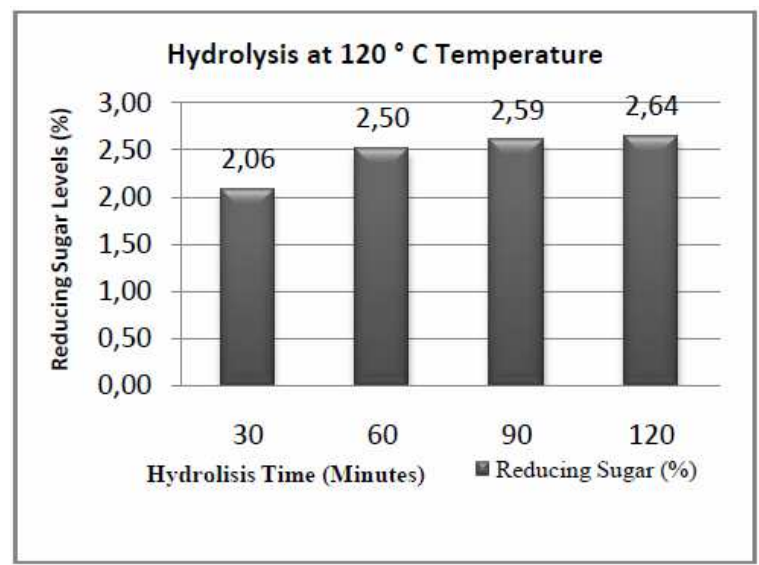

Fig. 1 Reducing sugar levels chart oil palm empty fruit bunch fibers were acid hydrolyzed at $120{ }^{\circ} \mathrm{C}$ temperature

If observed in Table 4 shows that the levels of reducing sugars increased with increasing time of hydrolysis at a temperature of $120^{\circ} \mathrm{C}$. This indicates that there is an opportunity to raise the temperature higher in order to obtain reducing sugar levels higher. When the hydrolysis temperature was raised to $130^{\circ} \mathrm{C}$, it is seen that the reducing of sugar levels also increased with increasing time to 60 minutes. However, after that the addition of time is not effective because reducing sugar actually be down. From observation it can be seen that the highest levels of reducing sugars obtained on hydrolysis temperature of $130^{\circ} \mathrm{C}$ with a time of 1 hour is $3.51 \%$. This result is much higher than that obtained Apriyanti (2008), which is $0.22 \%$ with the same hydrolysis time. While to get the glucose levels of $0.78 \%$
Apriyanti takes hydrolysis time for 4 hours, with the concentration of sulfuric acid for hydrolysis is larger that is $10 \%$.

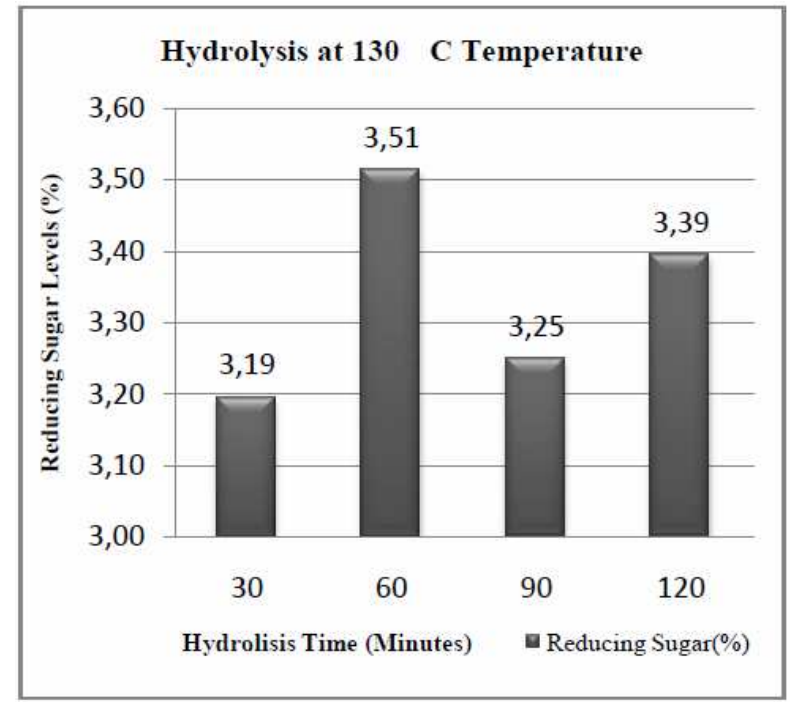

Figure 2.Rreducing sugar levels chart oil palm empty fruit bunch fibers were acid hydrolyzed at $130^{\circ} \mathrm{C}$ temperature

High levels of reducing sugar contained in sugar hydrolyzate, indicate the number of glucose contained in the hydrolyzate. Glucose is derived from the breakdown (hydrolysis) of cellulose because cellulose is a linear polymer of $\beta$-D-glucose are connected to each other by glycosidic bond of $\beta(1 \rightarrow 4)$. Cellulose is a polysaccharide carbohydrate group by the number of units of glucose or the degree of polymerization (DP)> 200 (Kusnandar, 2010), and can be as high as 10,000 (Deman, 1997). Reducing sugar is a sugar that is in a cyclic structure (Haworth projection) contained a hydroxyl group $(\mathrm{OH})$ on the free atom $\mathrm{C} 1$. Monosaccharides containing aldehyde group such as Dglucose and D-galactose, classified as a reducing sugar.

The results revealed that by controlling the temperature and time can increase the levels of reducing sugars obtained, with a shorter hydrolysis time. Expected with high levels of reducing sugars can be converted into ethanol which in this case is expected to be converted by the yeast Saccharomyces cereviciae, because yeast Saccharomyces cereviciae is very good in the production of ethanol. Alcohol yield from hexose sugars are fermented, can reach 90\% (Boyles, 1984 cit. Daud, 2010).

\section{Total Sugar Levels}

Total sugar is overall sugar component in hydrolyzed material, consisting of a reducing sugar and non-reducing sugar. Total sugar hydrolysis increases with increasing hydrolysis time also increased with increasing temperature (Table 5). However, this increase in temperature up to $130^{\circ} \mathrm{C}$ only 60 minutes (1 hour), passing of time, the additional hydrolysis time is no longer effective (Figure 3 and 4). This occurs due to the reducing sugar level, which decreases when the hydrolysis time increased more than 1 hour. 
Acid is a non-specific catalyst that can attack both cellulose and lignin. Cellulose is macromelocules with a very strong crystallinity, so that only a strong acid that can hydrolyze cellulose at a high conversion rate. As a nonspecific catalysts are highly reactive, strong acids also led to degradation of glucose hydrolysis. Acid hydrolysis of the lignocellulosic material at high temperatures and pressures, will be degraded xylose into furfural and lignin will be degraded to phenol units. (Lapierre et al., 1983 cit Apriyanti, 2008). So it is thought to be the cause of the decline in both reducing sugar and total sugar if the hydrolysis time increased again.

TABLE V

TOTAL SUGAR CONTENT OF OIL PALM EMPTY FRUIT BUNCH FIBERS WERE ACID HYDROLYZED WITH SOME COMBINATION OF TEMPERATURE AND HYDROLYSIS TIME

\begin{tabular}{|c|c|c|}
\hline $\begin{array}{c}\text { Hydrolysis Time } \\
\text { (Minutes) }\end{array}$ & \multicolumn{2}{|c|}{ Total S ugar Levels (\%) } \\
\cline { 2 - 3 } & Temperature $\mathbf{1 2 0}{ }^{\circ} \mathbf{C}$ & Temperature $^{\mathbf{1 3 0}}{ }^{\circ} \mathrm{C}$ \\
\hline 30 & 1.43 & 3.93 \\
60 & 1.92 & 4.30 \\
90 & 2.02 & 3.76 \\
120 & 2.17 & 3.78 \\
\hline
\end{tabular}

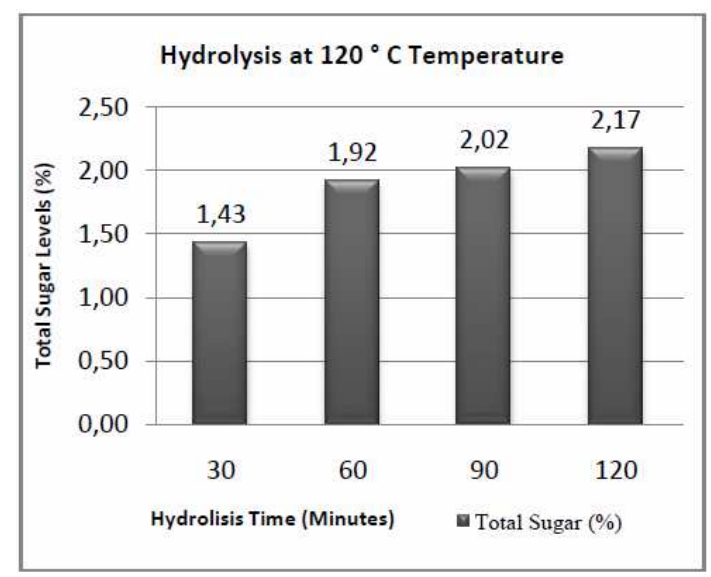

Fig. 3 Graph Sugar Levels Total oil palm empty fruit bunch fibers are hydrolyzed acid At $120^{\circ} \mathrm{C}$ Temperature

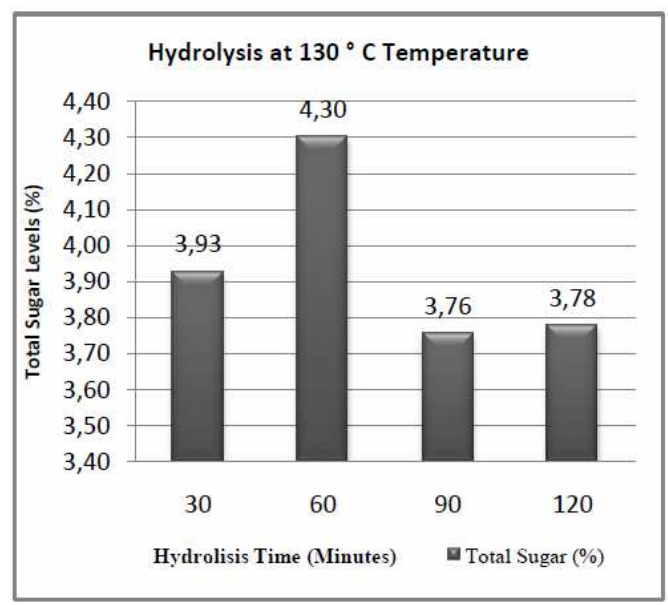

Fig. 4 Graph Sugar Levels Total Oil Palm Empty Fruit Bunch Fibers are Acid Hydrolyzed At $130^{\circ} \mathrm{C}$ Temperature

\section{IV.CONCLUSION}

From the research it can be concluded that the control of temperature and time can optimize the hydrolysis of oil palm empty fruit bunch fibers into sugar hydrolyzate that will be used as raw material for bioethanol production which is expected to be in the fermenting yeast Saccharomyces cereviceae, where hydrolysis time required to produce both highest reducing sugar and total sugar was 60 minutes at a temperature of $130^{\circ} \mathrm{C}$.

\section{REFERENCES}

[1] National Team for Biofuel Development. , 2008. BBN: Bio Fuel, Alternative Fuels Plant in lieu of Oil and Gas. Jakarta. Penebar Swadaya.

[2] Prihandana R., R. Hendroko. 2008. Green Energy: Towards Wise Choice Energy Independent State. Jakarta. Penebar Swadaya.

[3] Prihandana R., K. Noerwijati, P. Gamawati, Adinurani, D. Setyaningsih, S. Setiadi, R. Hendroko. 2007. Cassava bio-ethanol: Fuel of the Future. Jakarta. Agromedia Library.

[4] Daud M., 2010. Bioethanol production from Some Kind of Tropical Wood Through Process In Simultaneous Saccharification and Fermentation. [Thesis]. Bogor: Graduate School, Bogor Agricultural University.

[5] Kosaric N, Wieczorek A, Cosentino GP, Magee RJ \& JE Prenosil. 198.3 Ethanol fermentation, pp. 237-238. In: H Dellweg (ed.), Biotechnology, Vol. 3, Verlag Chemie, Weinheim.

[6] Apriyanti. , 2008. Straw Fermentation of Agricultural Waste Being In Ethanol. [Thesis]. Graduate, Andalas University. Padang.

[7] Anonymous. 1985. Chemisch-technologisches Spezialpractikum fuer Holzwirte. Ordinariate fuer Holztechnologie. Universitaet Hamburg. Hamburg Deutschland.

[8] Sudarmadji, S., B. Haryono Suhandri. , 1984. Analysis Procedures for Food and Agricultural Materials. Publisher Liberti Yogyakarta.

[9] HaroenWK., L. Fansukri. 1995. Manufacture of High Yield Pulp from Oil Palm Empty Fruit Bunch with NSSC process. Cellulose News / December 1995. Vol. XXXI, No. 4 Bandung.

[10] Andayani, R. 2012. Manufacture of Bioethanol from Oil Palm Empty Fruit Bunch Through Fungal Treatment Process by Aspergillus Niger and Fermentation by Zymomonas mobilis. Laboratory Waste Reduction. Institute of Ten Nopember Technology.

[11] Kusnandar, Feri. 2010. Food Chemistry: Macro Component. Dian Rakyat.

[12] deMan, John M. , 1997. Food Chemistry. Second Edition. Publisher ITB Bandung. Directorate of Agricultural Product Processing. 2006. Waste Reduction Guidelines for Oil Palm. Jakarta. Department of Agriculture. 